\title{
Out of the box: Protect the Unprotected
}

\author{
Aishwarya Maheshwari ${ }^{1}$ \\ ${ }^{1}$ Banda University of Agriculture and Technology
}

September 24, 2020

\begin{abstract}
No abstract - Ist paragraph of the article A species' ecological significance remains same whether it is found inside or outside a protected area (PA) then why the PAs are obligatory guarantor to maintain the biodiversity within their boundaries (Gascon et al. 2015)? Despite an increase in the number of PAs, connectivity is generally poor between and amongst the PAs, over $60 \%$ of PAs are too small to support major ecologically important and migratory species and eventually biodiversity is falling across the board (Coad et al. 2019). The PA approach, which was developed in the 20th century has been widely recognised as one of the most important strategies for achieving conservation goals (Shafer 2015). However, in the 21st century, it appears that PA based conservation approach has almost reached its practical and political limits (Coad et al. 2019; Shafer 2015) . Over the previous 1.5 century, the role of PAs was explored and expanded and both success and failures have been spectacular(Shafer 2015; Kalamandeen \& Gillson 2007; Butchart et al. 2010; Watson et al. 2014). Most of the PAs were established for the primary goal of conservation and later sustainable growth have now stretched to contribute towards livelihood, poverty reduction and national development (Shafer 2015). Over 202,000 PAs worldwide, cover almost 15\% of planet's surface under some practice of protection (Terraube et al. 2020). Moreover, substantial wildlife exists outside the PAs, where exact estimates are not available due to insufficient monitoring efforts (Cox \& Underwood 2011; McCleery et al. 2020).
\end{abstract}

\section{Out of the box: Protect the Unprotected}

Aishwarya Maheshwari

Department of Wildlife Sciences, College of Forestry, Banda University of Agriculture and Technology, Banda-210001, Uttar Pradesh, India (ORCID: 0000-0002-6338-4254).

aishwaryamaheshwari@icloud.com

A species' ecological significance remains same whether it is found inside or outside a protected area (PA) then why the PAs are obligatory guarantor to maintain the biodiversity within their boundaries (Gasconet al. 2015)? Despite an increase in the number of PAs, connectivity is generally poor between and amongst the PAs, over $60 \%$ of PAs are too small to support major ecologically important and migratory species and eventually biodiversity is falling across the board (Coadet al. 2019). The PA approach, which was developed in the $20^{\text {th }}$ century has been widely recognised as one of the most important strategies for achieving conservation goals (Shafer 2015). However, in the $21^{\text {st }}$ century, it appears that PA based conservation approach has almost reached its practical and political limits (Coad et al. 2019; Shafer 2015) . Over the previous 1.5 century, the role of PAs was explored and expanded and both success and failures have been spectacular(Shafer 2015; Kalamandeen \& Gillson 2007; Butchart et al. 2010; Watson et al. 2014). Most of the PAs were established for the primary goal of conservation and later sustainable growth have now stretched to contribute towards livelihood, poverty reduction and national development (Shafer 2015). Over 202,000 PAs worldwide, cover almost 15\% of planet's surface under some practice of protection (Terraube $e t$ al. 2020). Moreover, substantial wildlife exists outside the PAs, where exact estimates are not available due to insufficient monitoring efforts (Cox \& Underwood 2011; McCleery et al. 2020). 
Ensuring better management and coverage of the PAs, the United Nations Convention on Biological Diversity (CBD) set ambitious global biodiversity targets CBD-2010 and Aichi targets-2011 but financial support has been particularly inadequate to meet these targets (Butchartet al. 2010). The present COVID-19 crisis might disrupts fewer resources for biodiversity conservation, as much support is allocated to stabilize the pandemic (Gilbert 2010). Given the nature of the COVID-19 is zoonotic, it may motivate efforts to address limited usage of wildlife from the unprotected areas and the relationship between drivers of biodiversity loss and human health (Schulze et al. 2018). A landscape protection approach should be considered through, for instance, initiating actions to restore and develop unprotected areas into more productive buffer zones as corridors, through landscape restoration and conservation agriculture, farmland afforestation and improving the connectivity of isolated PAs. Such landscape protection approach has been practiced or suggested to conserve biodiversity beyond the PAs in Asia (Clark et al. 2013; Kshettry et al. 2015; Anon 2008), Africa (Wilson \& Primack 2019), Mediterranean region (Cox \& Underwood 2011) but lacking at the larger global scale.

The future is likely to bring new challenges in biodiversity conservation in the PAs (Schulze et al. 2018; Saura et al. 2019). In such context, biodiversity conservation in the unprotected areas will require unprecedented biodiversity-friendly actions and co-existence through integrated participatory approach, community based conservation with strong participatory rural appraisals, enabling agropastoral practices to meet biodiversity conservation and food security challenges, as well as ways to move from lose-lose to win-win situation.

\section{References}

1. Gascon, C., Brooks, T.M., Contreras-MacBeath, T., Heard, N. et. al. (2015). The Importance and Benefits of Species. Current Biology , 25, 431-438. https://doi.org/10.1016/j.cub.2015.03.041

2. Coad, L., Watson, J., Geldmann, J., Burgess, N.D., Leverington, F., Hockings, M., Knights, K. \& Di Marco, M. (2019). Widespread shortfalls in protected area resourcing undermine efforts to conserve biodiversity. Frontiers in Ecology and the Environment, 17, 259-264.

3. Shafer, Craig L. (2015). Cautionary thoughts on IUCN protected area management categories V-VI. Global Ecology and Conservation, 3, 331-348.

4. Kalamandeen, M. \& Gillson, L. (2007). Demything "wilderness": implications for protected area designation and management.Biodiversity Conservation , 16, 165-182.

5. Butchart, S.H.M., Walpole, M., Collen, B. et al. (2010). Global biodiversity: indicators of recent declines. Science, 328, 1164-1168. https://doi.org/10.1126/science.1187512

6. Watson, J.E.M., Dudley, N., Segan, D.B., \& Hockings, M. (2014). The performance and potential of protected areas. Nature, 515, 67-73. https://doi.org/10.1038/nature13947

7. Terraube, J., Van doninck, J., Helle, P. \& Cabeza, M. (2020). Assessing the effectiveness of a national protected area network for carnivore conservation. Nature Communications , 11. https://doi.org.10.1038/s41467-020-16792-7

8. Cox, R.L. \& Underwood, E.C. (2011). The Importance of Conserving Biodiversity Outside of Protected Areas in Mediterranean Ecosystems.PLoS One, 6, e14508. https://doi.10.1371/journal.pone.0014508

9. McCleery, Robert A., Fletcher Jr. R.J., Kruger, L.M., Govender, D. \& Ferreira, S.M. (2020). Conservation needs a COVID-19 bailout.Science, 369, 515-516. https://doi.org/10.1126/science.abd2854

10. Gilbert, N. (2010). More species means less disease. Nature, https://doi.org/10.1038/news.2010.644

11. Schulze, K., Knights, K., Coad, L., Geldmann, J., Leverington, F., Eassom, A., Marr, M., Butchart, S.H.M., Hockings, M., \& Burgess N.D. (2018). An assessment of threats to protected areas. Conservation Letters , 11, 1-10 https://doi.org/10.1111/conl.12435

12. UNEP-WCMC, IUCN and NGS (2018). Protected Planet Report 2018. UNEP-WCMC, IUCN and NGS: Cambridge UK; Gland, Switzerland; and Washington, D.C., USA. 